\title{
Constructing and Conducting an Interreligious Ecotheological Leadership in Environmental Science Perspective
}

\author{
Aloys Budi Purnomo
}

\begin{abstract}
Focus of this research is to examine the interreligious ecotheological leadership in environmental science perspective and how to conduct it in the real context to solve environmental problems. It cannot be done alone, but must be conducted with all others religions to face the environmental issue which is always demanding a leader figure to overcome it. However, there has not been a defining of the interreligious ecotheological leadership, a model of leadership conducted together from various religions leader to address ecological problems. The purpose of this research is to construct an interreligious ecotheological leadership and to reflect how such leadership is conducted in environmental science perspective. To achieve that objectives, this research used qualitative methods. Research data has been gained through seven months' involvement with the victims, that is the citizens experiencing brutal displacement in Tambakrejo, Semarang City of Indonesia. The data is combined with a documentary film "Tambakrejo \#BergerakBersama" and to be analyzed using the theory-developing research method as a desk-research type to construct the interreligious ecotheological leadership model as it has been conducted in the praxis. This research has demonstrated how important the interreligious ecotheological leadership is in the environmental science perspective for the ecological problems which must be addressed together. The results can inspire anyone in facing a similar case elswhere. The result is an eco-justice implementation for the poor and the oppressed. The results also show five traits that mark interreligious ecotheological leadership as mentioned in the discussion of this paper.
\end{abstract}

Keywords: ecological problems (issues), environmental science, interreligious ecotheology, interreligious ecotheological leadership

\section{INTRODUCTION}

$E_{\text {very time we are faced with the paradox of environmental }}$ narratives between global interests and local realities [1]. Tambakrejo case in Semarang City was one example, as a matter of ecological problem that does not stand alone but was in the context of the wider environmental problems in the city of Semarang. In 2015, Semarang City was selected as a

Revised Manuscript Received on December 30, 2019.

* Correspondence Author

Aloys Budi Purnomo*, Environmental Science Doctoral Program, Soegijapranata Catholic University, Semarang, Indonesia. Email: aloys@unika.ac.id

(C) The Authors. Published by Blue Eyes Intelligence Engineering and Sciences Publication (BEIESP). This is an open access article under the CC BY-NC-ND license (http://creativecommons.org/licenses/by-nc-nd/4.0/)

pilot project resilience city with 100 other cities in the world [2]. This became a challenge for the government, because during this time, the city of Semarang is called and stigmatized as "the Rob and Flood City" [3]. In such context, a good idea and step well was taken by the Mayor of Semarang to overcome the problems of rob and flood, by building a retention pool in Tawang, polder in Tanah Mas and the Banger polder; and the normalization of Rivers Flood West Canal (Banjir Kanal Barat) and of Flood East Canal one (Banjir Kanal Timur/BKT).

Apparently, the process of normalization of BKT affected to Tambakrejo resident case of eviction (on May 9, 2019). In an instant, their home was destroyed and flat ground. The people of Tambakrejo against this displacement supported by student activists, social community institutions (NGOs), legal aid institutions as well as artists, cultural and interreligious figures, including me as a diocesan priest of the Archdiocese of Semarang. Tambakrejo case is the concern of many parties in the perspective of integral liberation [4].

The life of residents of Tambakrejo in Semarang City has been started since 1989. Until February 2018, recorded, residents living in the area were 168 households. Their jobs are as small fishermen. As the fish are inseparable from water, the fishermen cannot be kept away from the sea. Therefore, the relocation to Rusunawa (Rumah susun sederhana sewa, Simple Stacking House Rental) provided by the government denied the residents. Responding to the rejection, the government of Semarang did the displacement in a brutal way. The displacement afflicts 97 households with at least 332 people, from children to the elderly [5].

To the people of Tambakrejo who experienced the unhuman displacement, the activists were present to accompany and to advocate them. I myself for seven months (May 9 November 30, 2019) intensively involved with the people of Tambakrejo through presence, communication of WhatsApp, in collaboration with artists and the interreligious figures in the halalbihalal Islamic moment, "Love Stage" music performance with artists and cultures, and various other forms of mentoring. All were done in the spirit of environmental leadership that will be referred to as the interreligious ecotheological leadership model, namely the leadership of friendly and caring human environment for the integrity of creation and environmental preservation.

Exactly, these are the main problem and objective of this research. Such leadership is analysed according to the literature review as will be explained in the following sections (part II of this paper). 


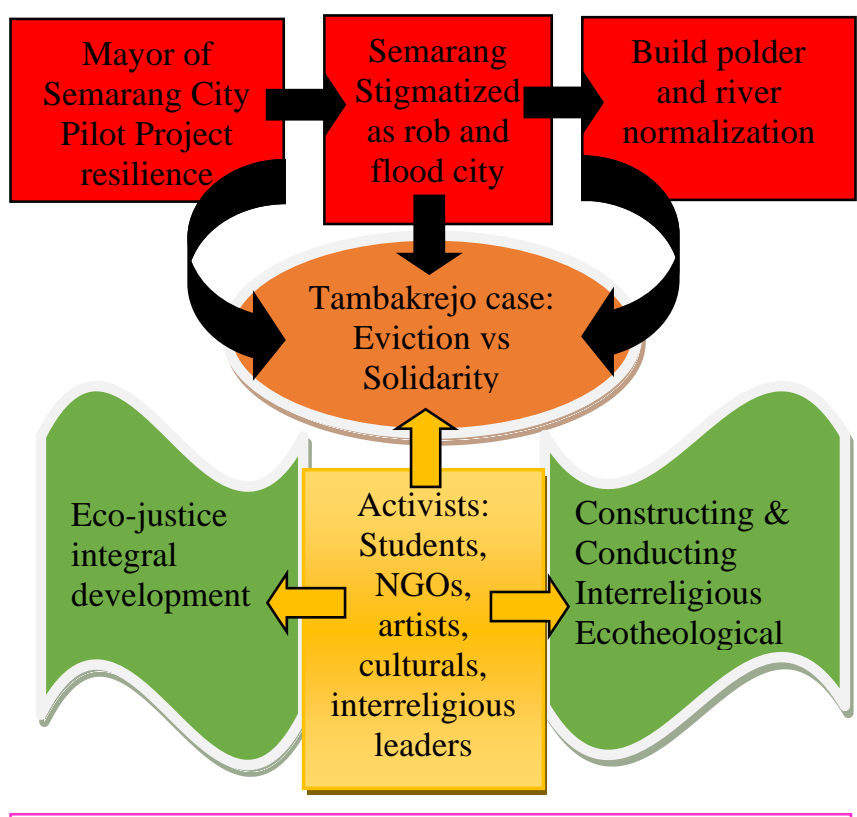

Figure 1: The problems and the main objectives

The praxis of involvement and related parties as well as the perspectives developed in this research as the problem and research purpose can be diagrammatically described in Figure 1.

\section{LITERATURE REVIEW}

Tambakrejo case moved the activists, artists, cultural and interreligious figures to accompany them in a humanitarian perspective. Referring to the ideas of Oprea and Cosmin, Julia Watts Belser, and Felix Wilfred, the activists based their practice of its companion in interreligious ecotheology, especially in eco-justice movement [6]-[8]. In the idea of Pope Francis, and Leonardo Boff their perspectives lensed by an ecological integral liberation [9]-[11]. According the Vatican Council II teaching, the anxieties of Tambakrejo people as the poor, the oppressed, and the abandoned after the eviction became the anxieties of the activist as well (cf. Gaudium et Spes 1). In ourr mind, Tambakrejo case represents the poor people screaming with the sick Earth screaming in the era of ecological crisis [12].

In the language of Leonardo Boff, the people of Tambakrejo needed solidarity, attention and compassion in accordance with the ecological principles of integral liberation [13]-[16]. They are the part of the universe being exploited through a violent displacement as the poor and the oppressed. People should not be victims of violence and government power [17]. The case of Tambakrejo emphasized the truth of the liberation praxis through ecological solidarity as mentioned by Leonardo Boff [18]. In the praxis, according to Abraham J. Heschel the activists listened to the screams of citizens as homo sympathetikos [19] as a form of preferential option for and with the poor on the basis of human compassions without intending to judge anyone [20].

Everything that has been heard from citizens in the praxis is delivered by the activists to the Mayor of Semarang in the spirit of dialog with an environmental and ecological perspective that always refers to the relationship between nature and the society that is inhabit as integral part of ecology. It is essentially called an ecological solidarity [21]. Every violation of solidarity and friendship among communities causes environmental damage from the perspective of humanity, because human beings have dignity to be respected and should not be manipulated in the name of development [22]. It is in accordance with Pope Francis who reminded that the citizens have the right to more fully and more smoothly achieve their perfection in reaching prosperity [23].

While respecting the city government's commitment to overcoming rob and flood, on behalf of the activists and the victim, I convey to the Mayor of Semarang that we must be steadfast in principle, gentle in the way, and prioritize love in all things. Referring to Leonardo Boff and Pope Francis, all was delivered prophetically in the ecological context of integral liberation and ecological repentance [24, 25]. Integral liberation ecology only succeeds when manifested in change for a better life. Without it, the problem will continue, the ecological crisis is becoming more tragic, even citizens will lose hope.

Following the theory of Felix Wilfred and Julia Watts Belser, the praxis of the activists in the case of Tambakrejo has represented the interreligious ecotheological one [26, 27]. In fact, more than a praxis of an interreligious ecotheology, the praxis itself has emerged a new model of interreligious ecotheological leadership model in facing the human ecological problem in the perspective of integral liberation. It is not as a solving problem, but rather as a guideline and orientation in action to face ecological issues as well as helping out the spiral of self-destruction, the environment and humanity [28]. The fruit expected from the interreligious ecotheological leadership in the perspective of the integral liberation as well as environmental science is the realization of a civilization of love for communities that are prosperous, dignified and faithful, whatever their religions [29].

\section{METHODOLOGY}

This research used a qualitative method [30]. Data obtained through the involving praxis in the field and integrated with documentary film "Tambak \#BergerakBersama" [31]. Then, it was analysed using the developing-theory research method as a desk-research type to construct the interreligious ecotheological leadership model as it has been implemented in the praxis in the Tambakrejo case [32]. I use the desk research method in processing praxis and combine it with the documentary film of "Tambakrejo \#BergerakBersama" because the film was done by others. By using materials produced by others, the research is called a desk research type [33].

The main subjects of the research population were displaced Tambakrejo residents and the activists involved in assisting the case, including the Mayor of Semarang City as the policy holder in the case. Action and reflection are conceptualized hermeneutically in the light of Laudato Si ', the concepts of interreligious ecotheology and integral liberation [34].

The analysis focuses on the interreligious ecotheological leadership model in an ecological integral liberation perspective. That would be called the interreligious ecotheological leadership in the perspective of humanity and environmental science. 
This leadership model is useful to contribute in an interdisciplinary sphere between Environmental Science and Interreligious

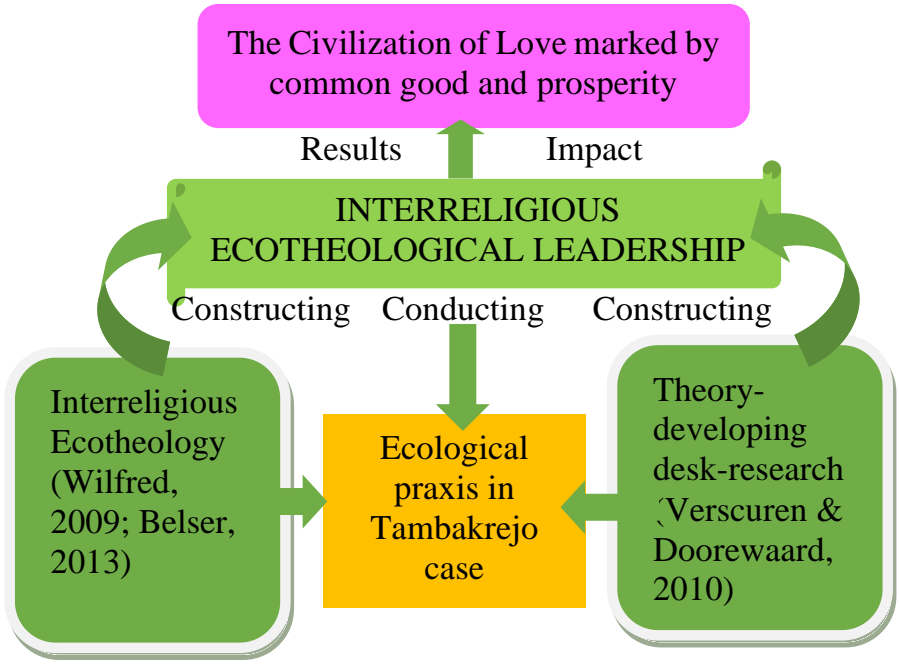

Figure 2: The methodological process of actions-reflections towards constructing-conducting of interreligious ecotheological Ecotheology with a humanitarian perspective, particularly in Indonesia, as the largest Muslim-populated country in the world. In this condition, we need a model of the interreligious ecotheological leadership in the face of every environmental issue.

Methodologically, the process of action and reflection based on the case of Tambakrejo to construct and to conduct interreligious ecotheological leadership with the result of the civilization of love marked by prosperity and common good can be described as Figure 2.

\section{RESULTS, DISCUSSION AND FINDINGS}

The results of conducting the interreligious ecotheological leadership model in environmental science perspective for the sake of integral liberation were very positive. In the side of the citizens, they become more patient, not aggressive, willing to cooperate for preparing a better future for their lives. Their grief was transformed into joy although still in misery because the residents still have to live in bulk in temporary residence. However, it's much better than staying in an emergency tent. Later on, Tambakrejo residents will enjoy a new life atmosphere in "Tambakrejo Fisherman Village of Semarang", which is built by the government with the master-plan and arrangement involving citizens and activists as recorded in the documentary film "Tambakrejo \#BergerakBersama" [35].

In the side of the government of the city, the Mayor of Semarang listened openly and gladly to the input of various parties. We do sit together on the basis of humanitarian principles to discuss the problem and to find the best way out in accordance with integral ecological principles. The Mayor does not only accept the victims but also visit to them lovingly. Residents are not so relocated, precisely made residential, even has been designed to be prepared fixed occupancy. The Mayor is also present inaugurated Mushola (a little Mosque) and the new TPQ (Taman Pendidikan Qur'an/Al Quran Education Park) for the citizens. In short, the Mayor accepted a new paradigm of development in eco-justice perspective. Even, honestly, the mayor called the citizens as faithful so that their struggles brought positive results.
As an ecological problem, Tambakrejo is considered to be difficult, complicated, interrelated, and it is not easily degraded and resolved. Tambakrejo case in the whole context can be called a wicked case that has several causes, many parties affected, and does not have a clear solution [36]. However, it turns out the case can be solved properly with a pattern of the interreligious ecotheological leadership approach based on faith, hope and love. Weighing regardless of environmental problems, there is always a way out of each person's native ecologically interreligious cooperation to realize the "civilization of love" in the society marked by common good and prosperity [37], [38]. Shortly, we can say the result constructing and conducting the interreligious ecotheological leadership is a civilization of ecological love without discrimination. The positive results in conducting interreligious ecotheological leadership in the case of Tambarejo can be can be described through the tabular form in Figure 3.

Tambakrejo case is an example that there is no complex environmental problem which cannot be solved when faced with a pattern of interreligious ecotheological leadership approach, the leadership that cares about the integrity of creation and the preservation of environment as an embodiment of faith, hope and love without discrimination. In the case of Tambakrejo, residents, student activists, NGOs, artists, cultures, interreligious figures and Mayor are representations of this leadership model.

As result and findings as well, the interreligious ecotheological leadership can be conceptualized as follows. The interreligious ecotheological leader is every person who never gives up to realize faith, hope and love for the integrity of creation and environmental preservation, regardless of their religions and beliefs.

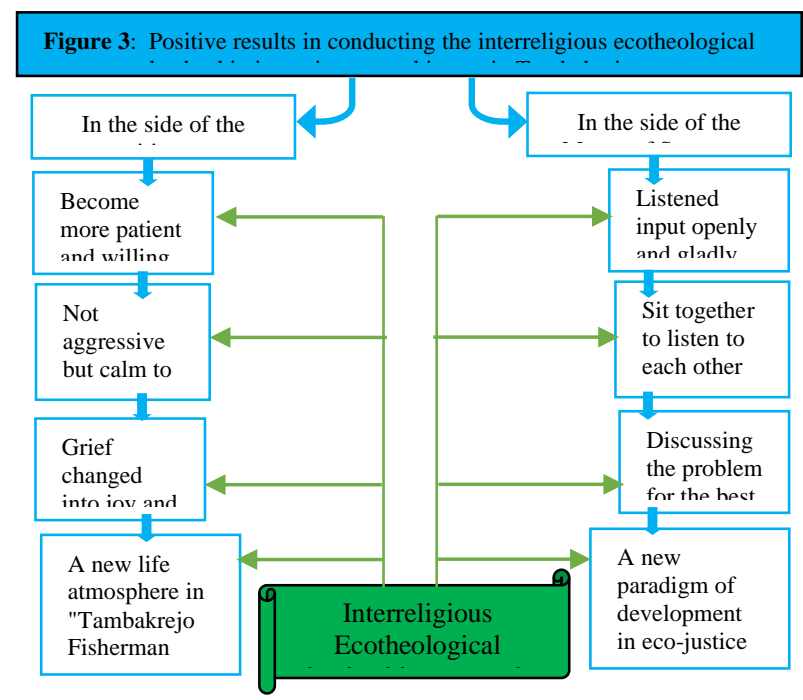




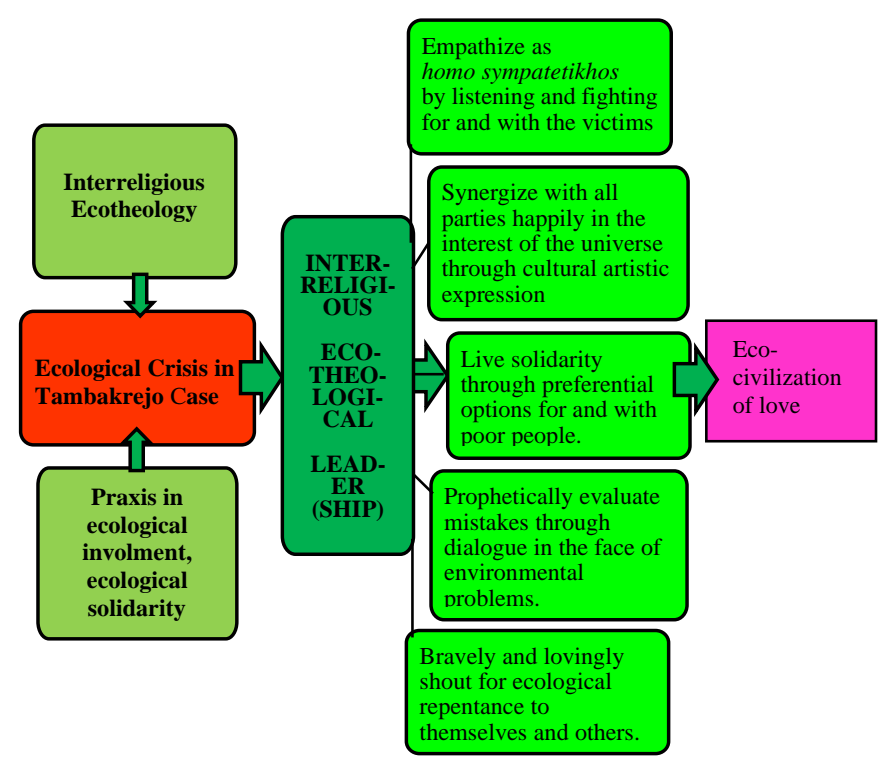

Figure 4: The characteristics of interreligious ecotheological leader(ship)

The life of the interreligious ecotheological leader marked by five traits as follows. First, empathize as homo sympathetikos to listen to and fight alongside the victims of environmental issues. Second, synergize with all parties happily in the interest of the universe through cultural artistic expression. Third, live solidarity through preferential options for and with poor people. Fourth, prophetically evaluate mistakes through dialogue in the face of environmental problems. Fifth, bravely and lovingly shout for ecological repentance to themselves and others.

Figure 4 illustrates the characteristics of the interreligious ecotheological leader. Both the results and research findings as presented in this paper are supported by data that we can see in the documentary film of "Tambakrejo \#BergerakBersama". The film features all the real facts and data as they are without deception or falsehood. All is about the real facts in the case of Tambakrejo.

\section{CONCLUSION}

Tambakrejo's case gave positive inspiration for the study of interreligious ecotheological leadership in environmental science perspective, not only to construct but also to conduct it in the ecological praxis. The question now is who is the interreligious ecotheological leader intended? First of all, she/he is every person who never gives up to practice faith, hope and love for the integrity of creation and environmental sustainability (preservation), regardless of her/his religion and belief. Furthermore, whoever has the basic character as described in Figure 4, she/he is the one worthy of being referred to as an interreligious ecotheological leader in the era of ecological crisis. Today and in the future, it is most urgent and needed of interreligious ecotheological leaders to maintain the integrity of creation and environmental sustainability in the perspective of environmental sciences as outlined in this paper.

Now, I hope, this study enriches environmental science with a new theory of interreligious ecotheological leadership model. Practically, the result contributes to a change in a better life and also becomes a model for addressing

environmental problems elsewhere. This research helps political leaders to make better policies.

\section{REFERENCES}

1. Widianarko, Budi. (2019, September 17), Paradoks Narasi Lingkungan. Harian Kompas. Retrieved from http://news.unika.ac.id/2019/10/paradoks-narasi-lingkungan/

2. Semarang Information Center and Rockefeller Foundation. Reselient Semarang: Moving Together towards a Resilient Semarang. Semarang City Government, 2016. p. 6.

3. Sudharto P. Hadi, Bunga Rampai Manajemen Lingkungan - Bagian Kedua. Semarang: Penerbit Thafa Media, 2019, pp. 107-111.

4. Anto Galon (2019). Documentary Film "Tambakrejo \#BergerakBersama".

https://drive.google.com/file/d/110MRodcjdsQLG4LVdi0w9P9si w mh2uH/view?usp=drivesdk

5. Ibid

6. Cristiana Oprea and Ciocan Tudor Cosmin, Ecotheological applicative researches. DIALOGO - International Journal of the Proceedings of the Conferences on the Dialogue between Science and Theology, Volume 3. https://doi.org/DOI: 10.18638/dialogo.2016.3.1.5, ISBN: 978-80-554-1285-6, ISSN: 2393-1744, vol. 3, issue 1, 2016, pp. 55-61.

7. Julia Watts Belser, (2013), Environmental Justice and Interreligious Ecotheology. Retrieved September 30, 2019, from Religious Studies News website: http://rsn.aarweb.org/spotlight-on/theo-ed/environemental-justice/envi ronmental-justice-and-interreligious-ecotheology

8. Felix Wilfred, (2009). Toward Inter-religious Eco-Theology. Concilium 2009/3. Retrieved from https://archive.org/details/ecotheology0000unse/page/n1, pp. 43-54.

9. Pope Francis, Laudato Si': On Care for Our Common Home. Vatican: Libreria Editrice Vaticana, 2015, pp. 46, 103-120.

10. Leonardo Boff, Cry of the Earth, Cry of the Poor. New York: Orbis Books, 1997. 104-114.

11. Leonardo Boff, Ecology and Liberation: A New Paradigm. New York: Orbis Books, 1995.

12. Leonardo Boff, 1997, ibid p. 81.

13. Leonardo Boff, Essential Care, An Ethics of Human Nature. Waco Texas: Baylor University Press, 2008, p. 2.

14. Daniel Schwindt, Catholic Social Teaching: A New Synthesis Rerum Novarum to Laudato Si'. USA: CPSIA, 2015, p. 162.

15. Pope Francis, (2015) p. 110

16. Leonardo Boff, (1997). Ibid., p. 10.

17. Aloys Budi Purnomo, Rakyat (Bukan) Tumbal Kekuasaan \& Kekerasan. Jakarta: Gramedia Pustaka Utama, 2005.

18. Leonardo Boff, (1997). pp. 104-105.

19. Heschel, Abraham. J., The Prophets. New York: Perennial Classics, 2001, p. 395.

20. Aloys Budi Purnomo, Preferential Option for and with the Poor. Medan: Bina Media, 2003, pp. 33-37.

21. Leonardo Boff, (1997), pp. 104-105.

22. Aloys Budi Purnomo, (2019). Mengakhiri Ketidakadilan Ekologis Pembangunan. Kompas, p. 6. Retrieved from

23. https://kompas.id/baca/opini/2019/08/07/mengakhiri-ketidakadilan-ek ologis-pembangunan

24. Pope Francis. (2015), pp. 46, 113-117.

25. Leonardo Boff, (1997), p. 188.

26. Pope Francis. (2015), pp. 157-159.

27. Felix Wilfred. (2009). Toward Inter-religious Eco-Theology Concilium 2009/3. Retrieved from https://archive.org/details/ecotheology0000unse/page/n1

28. Julia Watts Belser, (2013). Environmental Justice and Interreligious Ecotheology. Retrieved September 30, 2019, from Religious Studies News website: http://rsn.aarweb.org/spotlight-on/theo-ed/environemental-justice/envi ronmental-justice-and-interreligious-ecotheology

29. Pope Francis, (2015), p. 121.

30. Aloys Budi Purnomo, (2018, March 30), Peradaban Kasih Persaudaraan. Jakarta: Kompas, p. 7.

31. Steven R. Terrel, Writing a Proposal for Your Dissertation Guidelines and Examples. New York \& London: The Guilford Press, 2016. 
32. Anto Galon (2019). Documentary Film "Tambakrejo \#BergerakBersama". https://drive.google.com/file/d/110MRodcjdsQLG4LVdi0w9P9si_w $\mathrm{mh} 2 \mathrm{uH} / \mathrm{view}$ ?usp=drivesdk

33. Piet Verschuren and Hans Doorewaard, Designing A Research Project. The Haag: Eleven International Publishing, 2010.

34. Ibid, p. 194.

35. Anto Galon (2019). Documentary Film "Tambakrejo \#BergerakBersama".

36. https://drive.google.com/file/d/110MRodcjdsQLG4LVdi0w9P9si_w $\mathrm{mh} 2 \mathrm{uH} / \mathrm{view}$ ?usp=drivesdk

37. Ibid

38. Nicole M. Ardoin, Rachelle K. Gould, Elin Kelsey \& Priya Fielding-Singh (2015) Collaborative and Transformational Leadership in the Environmental Realm, Journal of Environmental Policy \& Planning, 17:3, 360-380, DOI: 10.1080/1523908X.2014.954075

39. Anne Marie Dalton and Henry C. Simmons, Ecotheology and Practice of Hope. New York: Sunny Press, 2010, p. 16.

40. Pope Francis. (2015), p. 147,167.

\section{AUTHOR PROFILE}

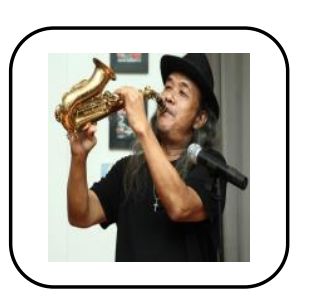

Aloy Budi Purnomo is a catholic diocesan priest of the Archdiocese of Semarang, Indonesia. He was ordained as a Roman Catholic priest on 8 July 1996. Now he serves as Head of Campus Ministry of Soegijapranata Catholic University and also student for Environmental Science Doctoral Program, Soegijapranata Catholic University, Jl. Pawiyatan Luhur IV/1 Bendan Dhuwur, Semarang 50234, Indonesia. He served as Chief of Interreligious Affair of the Archdiocese of Semarang (May, 2008 - May 2019). Some of his books that have been published include Membangun Teologi Inklusif-Pluralistik (Penerbit Kompas: Jakarta, 2004), Rakyat (Bukan) Tumbal Kekerasan \& Kekuasaan (Gramedia Pustaka Utama: Jakarta, 2005); Preferential Option for and with the Poor (Bina Media: Medan, 2003); The Wonderful Europe (Gramedia Pustaka Utama, 2011). He always enjoyed the baby saxophone strains which he played to entertain anyone, including the victims of violence and the displacement in Tambakrejo, Semarang. To him playing saxophone is an eco-happiness and an amazing grace as he always sings. He also actively wrote as a columnist in a number of newspapers in Indonesia. In 2004 he founded the monthly magazine of INSPIRASI, Lentera yang Membebaskan as Editor-in-Chief of the journalistic services. Completed the Theology Lisentiate study at the Pontifical Faculty of Wedabhakti, Yogyakarta and Master of Theology, Field of Contextual Theology Concentration, Sanata Dharma University of Yogyakarta, Indonesia (July 1996-February 1998). 